\title{
Pembentukan Mikronukleus di Mukosa Bukal akibat Paparan Senyawa Kimia pada Berbagai Macam Pekerjaan
}

\section{Deny Setiabudi, ${ }^{1}$ Rizki Amalina, ${ }^{2^{*}}$ Anggun Feranisa ${ }^{2}$}

\author{
${ }^{1}$ Program Pendidikan Dokter Gigi Fakultas Kedokteran Gigi Universitas Islam Sultan Agung, \\ Semarang, Indonesia \\ ${ }^{2}$ Departemen Biologi Oral Fakultas Kedokteran Gigi Universitas Islam Sultan Agung, \\ Semarang, Indonesia \\ Email: rizkiamalina@unissula.ac.id
}

\begin{abstract}
In general, an occupation could have hazzard and risk of exposure to genotoxic chemical compounds. These compounds could lead to micronucleus formation on buccal mucosa. This study was aimed to obtain the impact of chemical exposure on micronucleus formation in buccal mucosa at various occupations. This was a literature review study using databases of PubMed, ScienceDirect, and Google Scholar based on the keywords. The criteria of literatures were articles published in 2016-2021 using Indonesian or English language. The results showed that group compounds of polycyclic aromatic hydrocarbons (PAH), metals, carbamate, and organophospate, also compunds of silica, bezene, toluene, xylene (BTX), sevoflurane, desflurane, isoflurane, nitrous oxide, gemcitabin, and 5-fluoro uracil were genotoxic chemical compunds and could cause micronucleus formation in buccal mucosa of mechanics, grillers, miners, e-waste recyclers, construction workers, road markers, car painters, gasoline station workers, farmers, and healthcare workers. Genotoxic chemical compounds could be found excessively in occupational environment. These compounds could damage cells' DNA and caused micronucleus formation on buccal mucosa of workers. It is suggested to study further about cell damage biomarkers caused by genotoxic chemical compound exposure.
\end{abstract}

Keywords: micronucleus formation in buccal mucosa, chemical exposure of genotoxic compounds, occupational risk

\begin{abstract}
Abstrak: Suatu pekerjaan dapat memiliki risiko dan bahaya terpapar senyawa kimia yang bersifat genotoksik. Senyawa kimia tersebut dapat menyebabkan terbentuknya mikronukleus di mukosa pipi rongga mulut. Penelitian ini bertujuan untuk mengulas pengaruh paparan senyawa kimia pada berbagai macam pekerjaan terhadap pembentukan mikronukleus di mukosa bukal. Jenis penelitian ialah literature review. Penelusuran literatur melalui database PubMed, ScienceDirect, dan Google Scholar berdasarkan kata kunci yang sesuai. Kriteria literatur ialah terbitan tahun 2016-2021 dengan Bahasa Indonesia atau Inggris. Hasil penelitian mendapatkan senyawa kelompok polycyclic aromatic hydrocarbon (PAH), logam, carbamate, dan organophospate, serta senyawa silica, benzene, toluene, xylene (BTX), sevoflurane, desflurane, isoflurane, nitrous oksida, gemcitabin, dan 5-fluoro uracil merupakan senyawa kimia yang bersifat genotoksik dan dapat memicu pembentukan mikronukleus di mukosa bukal mekanik, pemanggang daging, penambang, pendaur ulang sampah elektronik, pekerja konstruksi, pekerja marka jalan, pengecat mobil, petugas SPBU, petani dan tenaga kesehatan. Senyawa kimia yang bersifat genotoksik banyak ditemukan di lingkungan pekerjaan. Senyawa tersebut dapat merusak DNA sel sehingga terbentuk mikronukleus di mukosa bukal pekerja. Disarankan untuk melakukan penelitian lanjut mengenai biomarker kerusakan sel akibat paparan senyawa kimia yang genotoksik.
\end{abstract}

Kata kunci: pembentukan mikronukleus di mukosa pipi, paparan senyawa kimia genotoksik, risiko pekerjaan 


\section{PENDAHULUAN}

Setiap pekerjaan memiliki risiko dan bahaya kesehatan kerja yang bermacammacam, mulai dari segi fisik, kimia, ergonomi, dan mikrobiologi. Pekerja memiliki risiko terpapar senyawa genotoksik yang berupa senyawa kimia. Senyawa tersebut berasal dari berbagai sumber yang ada di lingkungan kerja, seperti hasil pembakaran tidak sempurna dan paparan partikel kecil lainnya. Pekerja dapat terpapar dengan senyawa kimia secara langsung maupun melalui media lain, seperti udara dan air yang mengandung molekul yang mudah berikatan dengan senyawa kimia tersebut. ${ }^{1-6}$

Senyawa kimia yang bersifat genotoksik dapat menyebabkan kerusakan deoxyribonucleic acid (DNA) sel-sel tubuh pekerja yang dapat berdampak luas bagi tubuh pekerja. Salah satu gambaran dari kerusakan DNA yang ditimbulkan akibat paparan senyawa kimia ialah mikronukleus pada mukosa pipi rongga mulut $1,2,6-10$

Mikronukleus adalah tambahan nukleus kecil yang memiliki bentuk berupa massa kromatin sitoplasmik bulat hingga oval dan berada di sekitar nukleus utama. Mikronukleus terjadi akibat adanya senyawa genotoksik yang merusak kromosom sehingga menyebabkan kerusakan DNA. Hal ini menyebabkan tertinggalnya sebagian kromatid dan/atau kromosom pada tahap anafase yang selanjutnya akan terbungkus membran pada tahap telofase berakibat terbentuknya nukleus kecil yang disebut mikronukleus. ${ }^{1,11,12}$ Pembentukan mikronukleus yang diakibatkan berbagai macam senyawa genotoksik dapat menyebabkan kematian sel, ketidakstabilan genom, mutase. dan perkembangan keganasan. ${ }^{13}$

Penghitungan jumlah mikronukleus umumnya digunakan sebagai indikator awal adanya kerusakan DNA pada suatu sel. Uji mikronukleus telah banyak digunakan pada penelitian observasional terhadap subyek terpapar senyawa genotoksik yang berasal dari berbagai macam lingkungan pekerjaan. Uji mikronukleus banyak dipilih karena murah dan mudah dalam mendeteksi kerusakan DNA dini pada sel. ${ }^{1,2,12}$

Terpaparnya pekerja oleh suatu senyawa kimia di lingkungan pekerjaan dapat memicu terbentuknya mikronukleus di mukosa bukal pekerja. Dengan kemajuan teknologi dalam segala aspek maka semakin besar kemungkinan terpaparnya para pekerja oleh berbagai senyawa genotoksik. Hal ini yang mendorong penulis untuk membahas hubungan antara paparan senyawa kimia pada berbagai macam pekerjaan dengan pembentukan mikronukleus di mukosa bukal.

\section{METODE PENELITIAN}

Penelitian ini merupakan suatu literature review. Pencarian literatur dilakukan dengan cara memasukan masingmasing kata kunci pada database PubMed, ScienceDirect, dan Google Scholar. Literatur yang terseleksi ialah jenis artikel jurnal berupa original article atau review article dengan kisaran tahun 2016 hingga 2021 yang menggunakan bahasa Indonesia atau bahasa Inggris. Jurnal yang tidak menggunakan bahasa Indonesia atau bahasa Inggris, tidak tersedia dalam full text, dan jurnal yang tidak menjelasakan jenis pekerjaan serta jenis paparan senyawa kimia, tereksklusi dari pencarian literatur. Data jurnal dikumpulkan pada aplikasi Mendeley, yang merupakan perangkat lunak untuk membantu penulis memanajemen referensi.

\section{HASIL PENELITIAN}

Pada penelitian ini literatur diperoleh dari database PubMed $(n=8.366)$, ScienceDirect $(\mathrm{n}=105.238)$, dan Google Scholar $(n=422.350)$. Selanjutnya dilakukan skrining judul dan abstrak $(n=303)$ lalu penyesuaian dengan kriteria inklusi $(\mathrm{n}=120)$. Kemudian artikel-artikel tersebut dicek ketersediaan full-textnya, bahasa yang digunakan, serta ketersediaan informasi dari jurnal, sehingga didapatkan 56 artikel terpilih.

Penelusuran 56 artikel yang diperoleh mendapatkan 55 artikel internasional dan 1 artikel nasional, serta terdiri dari 49 artikel penelitian dan 7 artikel literature review. Terdapat 55 artikel yang menjelaskan mengenai risiko kesehatan akibat paparan senyawa kimia pada berbagai lingkungan pekerjaan. Selain itu terdapat 21 artikel yang menjelaskan mengenai dampak kesehatan 
akibat paparan senyawa kimia di lingkungan pekerjaan, dan 34 artikel menjelaskan dampak kerusakan seluler akibat paparan senyawa kimia di lingkungan pekerjaan.

Artikel mengenai kerusakan seluler akibat paparan senyawa kimia di lingkungan pekerjaan mengguanakan indikator berbeda-beda. Indikator yang digunakan seperti kerusakan oksidatif dan perubahan kromosom $(n=4)$, analisis biokimia dan hemato- logik $(n=5)$, dan analisis jumlah mikronukleus $(\mathrm{n}=25)$. Artikel yang menjelaskan jumlah mikronukleus di mukosa bukal berjumlah 24 buah.

Tabel 1 memperlihatkan jumlah mikronukleus di mukosa bukal para pekerja akibat paparan senyawa-senyawa kimia dari berbagai produk yang ada pada berbagai macam pekerjaan.

Tabel 1. Tabel jumlah mikronukleus di mukosa bukal akibat paparan senyawa kimia di berbagai macam pekerjaan

\begin{tabular}{|c|c|c|}
\hline Senyawa Kimia & Jenis Pekerjaan & Jumlah Mikronukleus \\
\hline \multirow{10}{*}{$\begin{array}{l}\text { PAH } \\
\text { (Benzo[a]pyrene, } \\
\text { Benz[a]anthracene, } \\
\text { Indeno[1,2,3-c,d]pyrene, } \\
\text { Dibenz[a,h]anthracene) }\end{array}$} & Penambang batubara $^{11}$ & $25,83 \pm 13,28$ \\
\hline & Pedagang kaki lima ${ }^{14}$ & $9,40 \pm 4,46$ \\
\hline & Pemanggang kacang ${ }^{15}$ & $5,23 \pm 1,41$ \\
\hline & Petugas SPBU ${ }^{16}$ & $2,50[1,60-3,30]$ \\
\hline & Traffic controller dan supir taksi ${ }^{17}$ & $2,78 \pm 0,62$ \\
\hline & Pemanggang daging ${ }^{18}$ & $18,97 \pm 3,77$ \\
\hline & Mekanik mobil ${ }^{19}$ & $16,89 \pm 10,16$ \\
\hline & Tukang las ${ }^{20}$ & $4,19 \pm 3,57$ \\
\hline & Pendaur ulang sampah elektronik ${ }^{21}$ & 2706 \\
\hline & Pekerja konstruksi terowongan ${ }^{22}$ & $2,00[1,00]$ \\
\hline \multirow{6}{*}{$\begin{array}{l}\text { Golongan logam } \\
\text { (aluminium, besi, kromium, } \\
\text { nikel, merkuri, arsen, sele- } \\
\text { nium, kadmium, tembaga, } \\
\text { rubidium, bromin) }\end{array}$} & Penambang batubara ${ }^{11}$ & $25,83 \pm 13,28$ \\
\hline & Pekerja pelapisan besi ${ }^{23}$ & $45,00[20,00-130,00]$ \\
\hline & Tukang las ${ }^{20}$ & $4,19 \pm 3,57$ \\
\hline & Pendaur ulang sampah elektronik ${ }^{21}$ & 2706 \\
\hline & Pekerja gudang semen ${ }^{24}$ & $15,00[13,30]$ \\
\hline & Petani kedelai ${ }^{25}$ & $3,30 \pm 2,10$ \\
\hline \multirow[t]{3}{*}{ Karbamat dan organofosfat } & Petani padi ${ }^{26}$ & $15,39 \pm 3,34$ \\
\hline & Petani kedelai $^{25}$ & $3,30 \pm 2,10$ \\
\hline & Petani rumah kaca ${ }^{27}$ & $3,55 \pm 2,95$ \\
\hline \multirow[t]{3}{*}{ Silika } & Pekerja marka jalan ${ }^{28}$ & $1,00[0,78-1,22]$ \\
\hline & Pekerja gudang semen ${ }^{24}$ & $15,00[13,30]$ \\
\hline & Pekerja konstruksi ${ }^{29}$ & $19,79 \pm 3,54$ \\
\hline \multirow{4}{*}{$\begin{array}{l}\text { Kelompok BTX } \\
\text { (Benzene, Toluene, Xylene) }\end{array}$} & Petugas SPBU ${ }^{16}$ & $2,50[1,60-3,30]$ \\
\hline & Petugas SPBU ${ }^{30}$ & $19,25 \pm 0,89$ \\
\hline & Pengecat mobil ${ }^{31}$ & $12,57 \pm 3,43$ \\
\hline & Petugas SPBU ${ }^{32}$ & $4,65 \pm 2,00$ \\
\hline Obat-obatan & Anestesiologis ${ }^{33}$ & $0,38 \pm 1,28$ \\
\hline $\begin{array}{l}\text {-Sevoflurane, desflurane, } \\
\text { isoflurane, } \mathrm{N}_{2} \mathrm{O}\end{array}$ & Tenaga kesehatan ${ }^{34}$ & $1,37 \pm 2,19$ \\
\hline -Gemcitabin, 5-fluoro uracil & Perawat $^{35}$ & $2,25[2,33]$ \\
\hline
\end{tabular}




\section{BAHASAN}

Mikronukleus adalah nukleus kecil yang berada di sebelah nukleus utama pada suatu sel, yang disebabkan oleh stimulasi senyawa genotoksik. ${ }^{1,11-13}$ Senyawa genotoksik dapat berupa suatu senyawa kimia yang dengan mudah berikatan dengan molekul senyawa di sekitarnya. Selain itu, senyawa genotoksik juga dengan mudah dapat masuk kedalam tubuh manusia melalui paparan molekul lain tersebut maupun secara langsung. ${ }^{1-5}$

International Agency for Research on Cancer (IARC) telah menglasifikasi beberapa senyawa kimia yang bersifat genotoksik maupun karsinogenik. Beberapa di antara senyawa-senyawa tersebut ialah polycyclic aromatic hydrocarbon ( $\mathrm{PAH})$, heterocylic amines (HCAs), benzene, dan formaldehid. Selain itu, IARC juga menglasifikasi debu material (silika, kayu, logam) dan obat antineoplastik sebagai karsinogen karena memiliki kandungan senyawasenyawa karsinogenik yang juga dapat memicu terbentuknya mikronukleus di mukosa bukal. 1,12,18,28,35-41

Berdasarkan hasil kajian penelitian ini didapatkan bahwa mikronukleus pada rongga mulut yang diakibatkan oleh senyawa kimia kelompok PAH menunjukkan jumlah yang tinggi dan banyak ditemukan pada berbagai macam pekerjaan. Senyawa $\mathrm{PAH}$, seperti benzo[a]pyrene, benz[a]anthracene, indeno[1,2,3-c,d]pyrene, dan dibenz[a,h]anthracene, banyak ditemukan di udara bebas. Senyawa tersebut umumnya berasal dari pembakaran tidak sempurna dengan bahan bakar organik seperti kayu, minyak bumi, arang, dan batubara. ${ }^{11,14-22,31}$

Senyawa PAH bersifat lipofilik dan dapat dengan mudah masuk ke dalam sel suatu organisme. Senyawa ini dimetabolisir oleh enzim cytochrome P450 (CYP450) serta beberapa enzim lainnya dalam sel tubuh manusia. Metabolit dari PAH di dalam sel tubuh manusia dapat berikatan dengan DNA membentuk DNA adducts yang bersifat karsinogenik terhadap tubuh. Senyawa reactive oxygen species (ROS) juga terbentuk selama proses metabolisme PAH berlangsung, yang akan berdampak pada terjadinya stres oksidatif serta kerusakan oksidatif DNA sehingga memicu pembentukan mikronukleus. ${ }^{12,42-45}$

Senyawa benzene, toluene, xylene merupakan senyawa organik yang mudah menguap dan juga kontaminan udara terbesar selain PAH. ${ }^{16,31,30,32,39}$ Senyawasenyawa tersebut, terutama benzene, akan dioksidasi di dalam hati oleh enzim CYP450 menjadi benzene oxide yang dapat tersusun ulang secara nonenzimatik menjadi fenol, diubah menjadi catechol, atau menjadi senyawa benzene diol epoxide yang bersifat karsinogenik. Fenol dan catechol di dalam tubuh akan mudah mengalami siklus redoks yang menghasilkan senyawa semikuinon yang karsinogenik dan senyawa ROS yang dapat memicu kerusakan oksidatif. 1,30,32,46-48

Kelompok logam juga banyak ditemukan pada lingkungan pekerjaan serta menimbulkan pembentukan mikronukleus di mukosa bukal. Alumunium, kromium, besi, nikel, tembaga, merkuri, arsen, dan silika merupakan beberapa senyawa logam yang dapat memicu terbentuknya mikronukleus di mukosa bukal. ${ }^{11,21,23,24,28,29}$ Senyawa logam di dalam tubuh manusia dapat menginduksi karsinogenesis dengan cara menghasilkan radikal bebas di dalam sel tubuh serta mengganggu protein regulasi dan protein pesinyal (signalling protein) seperti tembaga yang dapat menggantikan seng di protein regulasi tertentu dan menimbulkan gangguan pada proses transkripsi. Selain menginduksi karsinogenesis, ion logam juga dapat memroduksi senyawa ROS melalui berbagai macam reaksi kimia. Reaksi Fenton, reaksi Haber-Weiss, dan reaksi reduksi atau oksidasi lain dari molekul tubuh akibat ion-ion logam merupakan reaksi senyawa kimia yang berperan dalam produksi senyawa ROS akibat senyawa logam. Akumulasi senyawa ROS tersebut dapat memicu kerusakan DNA dan terbentuknya mikronukleus. ${ }^{1,28,23,49}$

Beberapa studi juga menjelaskan bahwa paparan pestisida dan pupuk pada petani dapat menyebabkan pembentukan mikronukleus. Hal tersebut dikarenakan adanya kandungan senyawa-senyawa kimia yang bersifat genotoksik dalam pestisida yang 
digunakan, antara lain golongan karbamat dan orgamofosfat. Pestisida umumnya dimetabolisir dalam dua fase pada tubuh manusia. Reaksi fase pertama dimediasi oleh enzim kelompok CYP450 dan menghasilkan metabolit intermediet yang selanjutnya akan diolah menjadi produk hidrofilik oleh enzim-enzim seperti $U D P$ glucuronosyltransferases (UGT), sulfotransferases (SULT), glutathione S-transferases (GST), dan $N$-acetyltransferases (NAT). Produk hidrofilik dari metabolisme pestida dapat dengan mudah diekresi oleh tubuh, sedangkan metabolit intermediet dari pestisida dapat memicu produksi senyawa ROS berlebihan di dalam sel dan mengurangi sistem antioksidan di dalam tubuh sehingga menimbulkan stres oksidatif. Selain itu pupuk yang digunakan pada pertanian umumnya juga mengandung senyawa logam, yang juga dapat memicu terbentuknya mikronukleus. ${ }^{25-27,50-54}$

Tenaga keseahatan juga memiliki risiko terpapar senyawa kimia yang dapat memicu terbentuknya mikronukleus di mukosa bukal. Tenaga kesehatan seperti anestesiologis dan perawat berisiko terpapar berbagai senyawa seperti sevoflurane, desflurane, isoflurane, dan nitrous oksida (N2O) pada gas sisa anestesi yang bersifat genotoksik. Selain itu, perawat dan tenaga medis dapat terpapar obat antineoplastik seperti gemcitabin dan 5-fluoro uracil, yang juga bersifat genotoksik. Obat-obatan tersebut dapat merusak DNA dengan cara berikatan langsung dengan DNA atau ribonucleic acid (RNA), alkilasi dari basa DNA atau ikatan fosfodiester DNA, menghambat replikasi DNA, serta menghambat kerja enzim topoisomerase pada DNA. $1,35,33,34$

Error! Reference source not found. memperlihatkan jumlah mikro-nukleus di mukosa bukal pekerja akibat paparan senyawa-senyawa kimia dari berbagai produk yang ada pada berbagai macam pekerjaan. Senyawa-senyawa kimia tersebut seperti kelompok PAH (benzo[a]-pyrene, benz[a]anthracene, indeno[1,2,3c,d]pyrene, dan dibenz[a,h]antrachene), golongan logam (alumunium, besi, kromium, nikel, merkuri, arsen, selenium, kadmium, tembaga, rubidium, bromin), karbamat, dan organofosfat, serta senyawa silika, BTX, sevoflurane, desflurane, isoflurane, $\mathrm{N} 2 \mathrm{O}$, gemcitabin, serta 5-fluoro uracil, merupakan senyawa genotoksik dan dapat menimbulkan terjadinya mikornukleus pada mukosa bukal pekerja. $1,15,24,25,31,33,35$

Jumlah mikronukleus tersebut umumnya memiliki perbedaan bermakna dengan kelompok yang tidak terpapar senyawa kimia. Walaupun demikian, masing-masing pekerjaan juga memiliki angka rerata yang berbeda satu sama lain. Perbedaan jumlah mikronukleus tersebut didasari oleh berbagai macam faktor seperti perbedaan perhitungan mikronukleus, usia serta kondisi kesehatan subyek, lama paparan, frekuensi harian paparan, dan/atau penggunaan alat pelindung diri pada subyek yang diteliti. $18,26,30,32$

Berdasarkan studi yang dikaji, lama paparan senyawa kimia bermacam-macam, mulai dari 2 tahun hingga 30 tahun kerja. Pekerja dengan durasi pekerjaan yang lama memiliki risiko tinggi terjadinya pembentukan mikronukleus di mukosa pipi rongga mulut. Peningkatan paparan senyawa kimia dapat mengakibatkan berbagai macam gangguan pada tubuh pekerja, seperti iritasi pada organ luar, gangguan hematologik, pengurangan fungsi pernapasan, gangguan sistem reproduksi, dan menurunnya sistem kekebalan tubuh terhadap kerusakan DNA. Selain itu, pekerja berusia di atas 30 tahun juga memiliki risiko tinggi terbentuknya mikronukleus. Hal tersebut menunjukkan adanya hubungan antara frekuensi dan kuantitas paparan senyawa kimia serta kondisi kesehatan seseorang dengan tingkat pembentukan mikronukleus di mukosa bukal. ${ }^{11,16,18,23,32-34}$

Peningkatan jumlah mikronukleus berdampak pada kelangsungan hidup sel tubuh. Kerusakan DNA dan perubahan kromosom, gangguan siklus sel, penuaan dini, gangguan neurodegeneratif, stimulasi kematian sel, serta stimulasi sel onkogen sehingga terjadi keganasan, merupakan hal yang dapat ditimbulkan akibat jumlah mikronukleus yang meningkat. 


\section{DAFTAR PUSTAKA}

1. Hopf NB, Bolognesi C, Danuser B, Wild P. Biological monitoring of workers exposed to carcinogens using the buccal micronucleus approach: a systematic review and meta-analysis. Mutat Res. 2019;781:11-29.

2. Jain V, Lohra P, Priya B, Sindhu D. Buccal cell micronuclei assay: a non-invasive genotoxic marker. Int J Contemp Med Res. 2017;4(1):100-4.

3. Cervena T, Rossnerova A, Sikorova J, Beranek V, Vojtisek-lom M, Ciganek M, et al. DNA damage potential of engine emissions measured in vitro by micronucleus test in human bronchial epithelial cells. Basic Clin Pharmacol Toxicol. 2017;121:102-8.

4. Moyce SC, Schenker M. Migrant workers and their occupational health and safety. Annu Rev Public Heal. 2018;39:351-65.

5. Singh Z, Chadha P. Textile industry and occupational cancer. J Occup Med Toxicol. 2016;11:39.

6. Ngaruiya FW, Ogendi GM, Mokua MA. Occupational health risks and hazards among the fisher-folk in Kampi, Lake Baringo, Kenya. Env Heal Insight. 2019; 13:1178630219881463.

7. Roquelaure Y, Jégo S, Geoffroy-perez B, Chazelle E, Descatha A, Evanoff B, et al. Carpal tunnel syndrome among male French farmers and agricultural workers: is it only associated with physical exposure? Saf Heal Work. 2020;11:33-40.

8. Biswas G, Bhattacharya A, Bhattacharya R. Occupational health status of construction workers: a review. Int J Med Sci Public Heal. 2017;6(4):669-75.

9. Dadzie EK, Ephraim RKD, Afrifa J, Quaicoe R, Bediako BS, Duku BI, et al. Persistent exposure to wood smoke is associated with variations in biochemical and hematological indices among regular wood burners in the Cape Coast metropolis, Ghana. Sci Afr. 2019;4:e00100.

10. Awopeju OF, Nemery B, Afolabi OT, Poels K, Vanoirbeek J, Obaseki DO, et al. Biomass smoke exposure as an occupational risk: cross-sectional study of respiratory health of women working as street cooks in Nigeria. Occup Env Med. 2017;74(10):737-44.
11. Rahmad R, Dewi N, Rosida L. Pengaruh paparan batubara terhadap jumlah mikronukleus mukosa bukal pada pekerja tambang batubara di Kecamatan Murung Pudak Kabupaten Tabalong. Dentino J Ked Gigi. 2016;1(2):129-34.

12. Kaisar S, Kale U. Role of micronucleus as a potential biomarker in oral carcinogenesis. ec dent sci. 2019;18(4):749-54.

13. Srinivas US, Tan BWQ, Vellayappan BA, Jeyasekharan AD. ROS and the DNA damage response in cancer. Redox Biol. 2019;25:101084.

14. Recoleto KJA, Villarino AG. Micronucleus test in exfoliated buccal cells of female street vendors exposed to vehicular exhaust in Iligan City, Philippines. Int J Humanit Soc Sci. 2017;9(2):119-30.

15. de Oliveira Galvao MF, de Queiroz JDF, Duarte E de SF, Hoelzemann JJ, de Andre PA, Saldiva PHN, et al. Characterization of the particulate matter and relationship between buccal micronucleus and urinary 1-hydroxypyrene levels among cashew nut roasting workers. Env Pollut. 2017;220 (Pt.A):659-71.

16. Shaikh A, Barot D, Chandel D. Genotoxic effects of exposure to gasoline fumes on petrol pump workers. Int J Occup Env Med. 2018;9(2):79-87.

17. Boas DSV, Matsuda M, Toffoleto O, Garcia MLB, Marquezini MV, Saldiva PHN. Workers of Sao Paulo City, Brazil, exposed to air pollution: assessment of genotoxicity. Mutat Res. 2018;834:1824.

18. Guma-os ABM, Villarino AG. Micronucleus test in exfoliated buccal cells of barbecue grillers in Marawi City, Philippines. Int J Sci Manag Stud. 2019; 2(4):33-7.

19. León-mejía G, Luna-rodríguez I, Trindade C, Oliveros-ortíz L, Anaya-romero $\mathrm{M}$, Luna-carrascal $\mathrm{J}$, et al. Cytotoxic and genotoxic effects in mechanics occupationally exposed to diesel engine exhaust. Ecotoxicol Env Saf. 2019; 171:264-73.

20. Aksu I, Anlar HG, Taner G, Bacanli M, Iritas $\mathrm{S}$, Tutkun E, et al. Assessment of DNA damage in welders using comet and micronucleus assays. Mutat Res. 2018; 843:40-5. 
21. Berame JS, Lapada AA, Miguel FF, Noguera EC, Alam ZF. Micronucleus evaluation in exfoliated human buccal epithelium cells among e-waste workers in Payatas, the Philippines. J Heal Pollut. 2020; 10(28):201213.

22. Villarini M, Guerrera E, Vannini S, Dominici L, Gianfredi V, Fatigoni C, et al. Cytogenetic biomonitoring of road tunnel construction workers: buccal micronucleus cytome assay. Ann Ig. 2020;115.

23. El-Safty AMK, Samir AM, Mekkawy MK, Fouad MM. Genotoxic effects due to exposure to chromium and nickel among electroplating workers. Int $\mathbf{J}$ Toxicol. 2018;37(3):234-40.

24. Krishna L, Sampson U, Annamala PT, Unni KM, Binukumar B, George A, et al. Genomic instability in exfoliated buccal cement warehouse workers. Int J Occup Env Med. 2020;11(1):33-40.

25. de Oliveira AFB, de Souza MR, Benedetti D, Scotti AS, Piaza LS, Garcia ALH, et al. Investigation of pesticide exposure by genotoxicological, biochemical, genetic polymorphic and in silico analysis. Ecotoxicol Env Saf. 2019;179:135-42.

26. Hamid A, Baharuddin KS, Rajab NF, Lubis SH, Ishak I, Othman HF, et al. Micronucleus analysis in buccal swabs of paddy farmers from the east coast of Malaysia. Malays J Heal Sci. 2018;16:9-14.

27. Cobanoglu H, Coskun M, Coskun M, Çayir A. Results of buccal micronucleus cytome assay in pesticide-exposed and nonexposed group. Env Sci Pollut Res Int. 2019;26(19):19676-83.

28. Wultsch G, Nersesyan A, Kundi M, Al-serori $\mathrm{H}$, Knasmuller S. Induction of chromosomal damage in exfoliated buccal and nasal cells of road markers. $\mathbf{J}$ Toxicol Env Heal. 2019;82(17):969-76.

29. Leonardi S, Poma AM, Colafarina S, D'Aloisio F, Scatigna M, Zarivi O, et al. Ecotoxicology and environmental safety early genotoxic damage through micronucleus test in exfoliated buccal cells and occupational dust exposure in construction workers: a cross-sectional study in L'Aquila, Italy. Ecotoxicol Env Saf. 2020;203:110989.

30. Omar RA, Saleem MA, Karim KJ. Cytotoxicity in exfoliated buccal cells of petrol stations' workers in Erbil City. Int
Conf Pure Appl Sci. 2018;101-4.

31. Filho APDR, Silveira MAD, Dermaco NR, D'Arce LP. Increased DNA damage, instability and cytokinesis defects in occupationally exposed car painters. In Vivo (Brooklyn). 2019;33(6):1807-11.

32. Salih DJ, Qader MK, Ahmed MR. Genotoxic effects of benzene in petrol station workers in Duhok- Kurdistan region of Iraq. Haya Saudi J Life Sci. 2019; 4(4):143-7.

33. Souza KM, Braz LG, Nogueira FR, Souza MB, Bincoleto LF, Aun AG, et al. Occupational exposure to anesthetics leads to genomic instability, cytotoxicity and proliferative changes. Mutat Res. 2016;791:42-8.

34. Cakmak G, Eraydin D, Berkkan A, Yagar S, Burgaz S. Genetic damage of operating and recovery room personnel occupationally exposed to waste anaesthetic gases. Hum Exp Toxicol. 2019;38(1):310.

35. Ursini CL, Salè EO, Fresegna AM, Ciervo A, Jemos C, Maiello R, et al. Antineoplastic drug occupational exposure: a new integrated approach to evaluate exposure and early genotoxic and cytotoxic effects by no-invasive buccal micronucleus cytome assay biomarker. Toxicol Lett. 2019;316:20-6.

36. Beigzadeh Z, Pourhassan B, Kalantary S, Golbabaei F. Occupational exposure to wood dust and risk of nasopharyngeal cancer: a systematic review and metaanalysis. Env Res. 2019;171:170-6.

37. Pelclova D, Zdimal V, Kacer P, Zikova N, Komarc M, Fenclova Z, et al. Markers of lipid oxidative damage in the exhaled breath condensate of nano $\mathrm{TiO} 2$ production workers. Nanotoxicol. 2017; 11(1):52-63.

38. Petit P, Maître A, Persoons R, Bicout DJ. Lung cancer risk assessment for workers exposed to polycyclic aromatic hydrocarbons in various industries. Env Int. 2019;124:109-20.

39. Frigerio G, Campo L, Mercadante R, Mielzynska-Svach D, Pavanello S, Fustinoni S. Urinary mercapturic acids to assess exposure to benzene and other volatile organic compounds in coke oven workers. Int J Env Res Public Heal. 2020;17(5):1801.

40. Santiago F, Lima S, Antunes S, Silvestre RT, 
Scherrer LR, Alves G, et al. Immunophenotypic evaluation as a tool for monitoring risks for blood malignancies in gas station workers. Asian Pac J Cancer Prev. 2019;20(7):2109-15.

41. Abreu A, Costa C, Pinho e Silva S, Morais S, Pereira $\mathrm{M}$ do $\mathrm{C}$, Fernandes A, et al. Wood smoke exposure of Portuguese wildland firefighters: DNA and oxidative damage evaluation. J Toxicol Env Health Pt A. 2017;80(13-15):596-604.

42. Moorthy B, Chu C, Carlin DJ. Polycyclic aromatic hydrocarbons: from metabolism to lung cancer. Toxicol Sci. 2015; 145(1):5-15.

43. Abdel-Shafy HI, Mansour MSM. A review on polycyclic aromatic hydrocarbons: Source, environmental impact, effect on human health and remediation. Egypt J Pet. 2016;25:107-23.

44. Potapova T, Gorbsky GJ. The consequences of chromosome segregation errors in mitosis and meiosis. Biol. 2017;6(12):1-33.

45. Miller MR. Oxidative stress and the cardiovascular effects of air pollution. Free Rad Biol Med. 2020;151:69-87.

46. Ekpenyong CE, Asuquo AE. Recent advances in occupational and environmental health hazards of workers exposed to gasoline compounds. Int J Occup Med Env Heal. 2017;30(1):1-26.

47. Dewi R, Hamid ZA, Rajab NF, Shuib S, Razak SRA. Genetic, epigenetic, and lineagedirected mechanisms in benzene-induced malignancies and hematotoxicity targeting hematopoietic stem cells niche. Hum Exp Toxicol. 2019;1-19.

48. Carbonari D, Chiarella P, Mansi A, Pigini D, Lavicoli S, Tranfo G. Biomarkers of susceptibility following benzene exposure: influence of genetic polymorphisms on benzene metabolism and health effects. Biomark Med. 2016;10(2):145-63.

49. Engwa GA, Ferdinand PU, Nwalo FN, Unachukwu MN. Mechanismand health effects of heavy metal toxicity in humans. In: Karcioglu O, editor. Poisoning in the Modern World - New Tricks for an Old Dog?2. IntechOpen, 2019; p. 1-23.

50. Zepeda-Ace R, Rojas-Garcia AE, BenitezTrinidad A, Herrera-Moreno JF, MedinaDiaz IM, Barron-Vivanco BS, et al. Oxidative stress and genetic damage among workers exposed primarily to organophosphate and pyrethroid pesticides. Env Toxicol. 2017;32:1754-64.

51. Nicolopoulou-stamati P, Maipas S, Kotampasi C, Stamatis P, Hens L. Chemical pesticides and human health: the urgent need for a new concept in agriculture. Front Public Heal. 2016;4:148.

52. D'Souza UJA. Pesticide toxicity and oxidative stress: a review. Borneo J Med Sci. 2017;11(1):9-19.

53. Kaur R, Thakur Y. Metabolism of pesticides by human cytochrome P450 (CYPs). Int J Creat Res Thou. 2018;6(2):1293-300.

54. Jablonska-Trypuc A. Pesticides as inducers of oxidative stress. React Oxyg Species. 2017;3(8):96-110. 